\title{
HOW TO JUSTIFY MANDATORY ELECTORAL QUOTAS: A POLITICAL EGALITARIAN APPROACH
}

\author{
Attila Mráz* (ID \\ Harvard University, Edmond J. Safra Center for \\ Ethics, Cambridge, Massachusetts, United States; \\ Sciences Po Paris, CEVIPOF, Paris, France
}

\begin{abstract}
This paper offers a novel substantive justification for mandatory electoral quotase.g., gender or racial quotas - and a new methodological approach to their justification. Substantively, I argue for a political egalitarian account of electoral quotas. Methodologically, based on this account and a political egalitarian grounding of political participatory rights, I offer an alternative to the External Restriction Approach to the justification of electoral quotas. The External Restriction Approach sees electoral quotas as at best justified restrictions on political participatory rights. I argue for the Internal Restriction Approach instead, which can justify electoral quotas by specifying the pro tanto scope of political participatory rights rather than by justifying restrictions on the pro tanto scope of these rights. On this approach, adequately set electoral quotas do not even conflict with and are not balanced against political participatory rights, while electoral quotas — when justified — are pro tanto required rather than merely permitted.
\end{abstract}

\section{INTRODUCTION}

Several countries implement quotas to ensure members of ethnic, racial, national, or religious minorities, or women, participate in legislative

* My thanks to Eric Beerbohm, Péter Cserne, Adom Getachew, Roni Hirsch, Kriszta Kovács, Daniel Layman, Annabelle Lever, Meira Levinson, Anna Lewis, Anna Réz, Naomi Scheinerman, Jacob S. Sherkow, as well as to all members of the 2019-2020 Fellows-inResidence seminar of the Edmond J. Safra Center for Ethics at Harvard University, for inspiring comments on earlier drafts of this paper. Special thanks to Arthur Applbaum, Dmitrii Dorogov, Edmund Tweedy Flanigan, Gregory Keating, and Zoltán Miklósi for extensive and extremely helpful comments. Funding from the European Union's Horizon 2020 research and innovation program via the REDEM project (www.redem-h2020.eu) under grant agreement No. 870996 is gratefully acknowledged. 
assemblies. ${ }^{1}$ These quota measures may take many different shapes. They may apply to the output of an electoral procedure (specifying that a minimum ratio of legislative assembly seats is reserved for members of a certain group), they may apply to the procedure itself (specifying, e.g., that a minimum ratio of the candidates who appear on a party list or are otherwise affiliated with the party should be members of a certain group), or they may interfere with the way the input of electoral procedures is generated (e.g., by regulating the composition of the leadership bodies of political parties or the required content of party bylaws). What is common to these quota measures is that they (i) aim to increase the political influence of individuals belonging to disadvantaged groups by providing them with explicit, formally mandated advantages in political participation through electoral institutions where participation opportunities are scarce, and (ii) they do so by reserving some such opportunities for members of the disadvantaged groups concerned. ${ }^{2}$ I will refer to these measures as "electoral quotas." Such measures, whether they merely regulate the composition of public bodies or they also interfere with the inner life of political parties, are often represented in law and philosophy alike ${ }^{3}$ as just or unjust resolutions of a conflict of values or even of rights. On this approach-the External Restriction Approach - the moral evaluation of electoral quotas turns on a clash between a subset of political rights-namely, political participatory rights-on the one hand, and the principle of equal opportunity or a right to equal treatment, on the other. The former are taken to be proportionately or disproportionately restricted in pursuit of the latter, depending on whether you talk to proponents or opponents of electoral quotas.

In this paper, I aim to provide a novel justification of electoral quotas that relies on an entirely different approach-the Internal Restriction Approachto the relationship between political participatory rights and electoral quotas. On this new approach, what appears to be a conflict between political participatory rights and electoral quotas is, in some circumstances, no conflict at all. Political participatory rights are not restricted by properly justified and calibrated gender, racial, ethnic, etc., quotas. This is no mere reframing of a well-known problem. I argue that this new approach significantly changes the conditions in which quotas are justified: it justifies quota measures without a need to balance them against political participatory rights, and it grounds a pro tanto requirement rather than a mere permission to apply electoral quotas in certain circumstances.

1. See, e.g., Atlas of Electoral Gender Quotas (Drude Dahlerup et al. eds., 2013).

2. Such quota measures are a subset of the measures more generally referred to as "affirmative action." Affirmative action may also take other forms besides quota measures. For a detailed discussion, see infra Section VI.

3. See, e.g., Robert S. Taylor, Rawlsian Affirmative Action, 119 Ethics 476 (2009); Blanca Rodríguez Ruiz \& Ruth Rubio-Marin, The Gender of Representation: On Democracy, Equality, and Parity, 6 InT'L J. Const. L. 287 (2008). 
The structure of this paper is as follows. In Section I, I briefly outline the normative challenge of electoral quotas as they apply to various stages of the electoral procedure, summarizing what is prima facie objectionable about them given a concern with political participatory rights. In Section II, I present what I take to be the best justification for electoral quotas. In Section III, relying on a political egalitarian account of political participatory rights, I argue that the same justification grounds political participatory rights and electoral quotas, and hence there is no value conflict between them. In Section IV, I draw some implications of this approach to the relationship between political participatory rights and electoral quotas for policy evaluation. In Section V, I clarify how the existence of alternative, additional justificatory grounds of electoral quotas bears on my account. In Section VI, I show how my account of electoral quotas can account for the intuition that quotas are only justified if necessary to achieve their justificatory aim. In Section VII, I clarify the relationship between my argument and an apparently related general theory of rights. The final section concludes.

\section{THE CHALLENGE: POLITICAL PARTICIPATORY RIGHTS VS. ELECTORAL QUOTAS}

Some proponents and opponents of electoral quotas share the common assumption that quotas-justifiably or not-restrict or infringe on the political participatory rights of individuals. ${ }^{4}$ I will refer to this methodological approach to the relationship between political participatory rights and electoral quotas as the External Restriction Approach. ${ }^{5}$ On this approach, electoral quotas of all kinds are seen as restrictions on the "pro tanto scope" "coverage"7 — of political participatory rights, where this scope is determined only by reference to the normative grounds of the rights in question, without regard to any conflicting values. Opponents regard electoral quotas as unjustified restrictions on the pro tanto scope of these rights. Hence, in their view, electoral quotas should not restrict political participatory rights:

4. See Andrew Rehfeld, On Quotas and Qualifications for Office, in Political RePresentation 236, 239, 255-264 (Ian Shapiro, Susan C. Stokes \& Alexander S. Kirshner eds., 2010); cf. Noëlle Lenoir, The Representation of Women in Politics: From Quotas to Parity in Elections, 50 InT'L \& Comp. L. Q. 217, 236-237 (2001); Elisabetta Palici di Suni, Gender Parity and Quotas in Italy: A Convoluted Reform Process, 35 W. Eur. PoL. 380, 383 (2012). I use the terms "restriction" and "infringement" of a right interchangeably, to denote interferences with the pro tanto scope of a right that call for justification. Restrictions and infringements, as opposed to violations of a right, may or may not be justified. A violation is an unjustified restriction or infringement. This implies that there is logical space for justified restrictions; I do not assume that rightseven fundamental rights generally speaking-are absolute or unrestrictable.

5. Stephen Gardbaum uses the term "external limitation" in roughly the same sense as I use "external restriction” below. Stephen Gardbaum, Limiting Constitutional Rights, 54 UCLA L. REv. 789 (2007). Cf. Gardbaum, infra note 59.

6. George Letsas, The Scope and Balancing of Rights: Diagnostic or Constitutive?, in SHAPING RIGHTS in the ECHR: The Role of the European Court of Human Rights in Determining the Scope of Human Rights 38 (Eva Brems \& J. H. Gerards eds., 2013).

7. Frederick Schauer, Can Rights Be Abused?, 31 PHIL. Q. 225, 228-230 (1981). 
the all-things-considered scope-or "protection" - - of political participatory rights should extend exactly as far their pro tanto scope. In contrast, proponents see electoral quotas as justified restrictions on the pro tanto scope of political participatory rights. Hence, in their view, the all-things-considered protection of political participatory rights should be narrower than their pro tanto scope. ${ }^{9}$

This section outlines the different types of electoral quotas that the External Restriction Approach sees as different types of infringements on political participatory rights. This initial mapping is meant to pave the way for a more substantive normative discussion in the following sections. ${ }^{10}$ I do not critique the External Restriction Approach, but only present it in order to raise awareness of the challenges involved in justifying electoral quotas, and to contrast it with my alternative account: the Internal Restriction Approach. I will present alleged infringements in an ascending order of severity. ${ }^{11}$ At the same time, I will also outline the pro tanto scope and content of political participatory rights on the External Restriction Approach to make initial sense of these alleged infringements. Thus, this

\section{Id.}

9. Note that the distinction between scope/coverage and protection, and the equivalent distinction between pro tanto and all-things-considered scope, are both orthogonal to the Rawlsian distinction between prima facie rights and fundamental or basic rights. The latter distinction corresponds to the idea that some rights—viz, the basic ones-can only be restricted subject to special justificatory requirements. See John Rawls, Justice as Fairness: A Restatement (Erin Kelly ed., 2001), at 294; and, more recently, Åsbjørn Melkevik, The Fictitious Liberal Divide, 10 Erasmus J. Phil. \& Econ. 1, 9-10 (2017). I will assume throughout that political participatory rights are fundamental or basic, i.e., that they can be restricted but only subject to special justificatory requirements.

10. The normative challenge of justifying electoral quotas can be-and often has been-formulated in terms of "reverse discrimination." This framing focuses on alleged violations of equality (equal treatment) that quota measures impose on those whose interests are set back by these measures. Hence, the main normative challenge on this reading is to reconcile two allegedly conflicting requirements of equality (equal opportunities for the beneficiaries of quota measures; equal treatment for those whose interests are set back by these measures), instead of reconciling political rights with equality. For such a characterization of the challenge that affirmative action measures-including quotas-represent, see, among others, RonALD Dworkin, Taking Rights Seriously (1977), at 223-239 (in support of affirmative action); Louis P. Pojman, The Case Against Affirmative Action, 12 InT'L J. Applied Phil. 97 (1998) (against affirmative action); Kasper Lippert-Rasmussen, Making Sense of Affirmative Action (2020), at 159-172 (analyzing the "reverse discrimination" characterization of affirmative action); and Hopwood v. Texas, 78 F.3d 932 (5th Cir. 1996) (finding that race may not be used as a factor in deciding between applicants in university admissions), since abrogated by Grutter v. Bollinger, 539 U.S. 306 (2003). In this paper, however, I focus on a characterization of the main challenge as an alleged conflict between political participatory rights and equality, for two reasons. First, while legal practice sees one of the main challenges of justifying quotas in these terms, philosophical discussion has failed to sufficiently address this aspect of the debate. Second, while any conception of equal treatment needed to generate the challenge on equality vs. equality terms is implausibly formalistic, in my view, I do not believe that a conception of political participatory rights needed to generate the challenge in political rights $v$ s. equality terms is similarly prima facie implausible.

11. By "severity," I mean how hard it is to justify the quota measure. Thus I use the standard of severity that Lippert-Rasmussen refers to as the "normative principle-based view" of the strength of an affirmative action measure. LIPPERT-RASMUSSEN, supra note 10, at 17. 
section is meant to lend some plausibility to the resistance to electoral quotas as a challenge to political participatory rights. The following presentation of electoral quota regimes is inspired by Drude Dahlerup's classification, ${ }^{12}$ but unlike her descriptive typology, it takes a normative approach to classification. Let us consider, then, the different types of electoral quotas according to how severely they are alleged to interfere with political participatory rights:

Output quotas ${ }^{13}$ prescribe a minimum ratio or number of seats in a legislative assembly-for example, a requirement that 30 percent of parliamentary seats be allocated to female representatives, ${ }^{14}$ or representatives of a given ethnic minority. Hence, such quotas regulate the output of the electoral procedure. ${ }^{15}$ This quota type can be seen as infringing on the fundamental or basic right to vote: no matter what electoral preferences have been expressed in the electoral procedure, some candidates preferred by the majority of the electorate may not take their seats in elected assemblies. ${ }^{16}$ Further, such quotas can be seen as infringing on the right to stand for election -also a fundamental or basic right. ${ }^{17}$ Opponents of electoral quotas may assume that the latter pro tanto right entails an entitlement to serve as an elected representative if and only if one is elected as a representative. ${ }^{18}$ Output quotas are thus seen as a threat to both the right to vote and the

12. Drude Dahlerup, Introduction, in Women, Quotas and Politics 1, 21 (Drude Dahlerup ed., 2006).

13. Output quotas are also often referred to alternatively as "reserved seats." See Mona Lena Krook, Quotas for Women in Politics: Gender and Candidate Selection Reform Worldwide (2009), at 4-18. There is some controversy in the descriptive literature as to whether reserved seats qualify as electoral quotas at all. In taking the comprehensive approach, I am following Dahlerup on gender quotas. Dahlerup, supra note 12, at 19.

14. For an example of existing output quota measures in Mexico, see Lisa Baldez, Elected Bodies: The Gender Quota Law for Legislative Candidates in Mexico, 29 Legis. STud. Q. 231 (2004).

15. Output quotas, however, are impracticable on their own: their implementation-without accompanying procedural or input quotas-requires an agreement between competing parties to ensure the adequate overall composition of the legislative assembly.

16. See Rehfeld, supra note 4, at 239, 255-256. As Rehfeld puts it, eligible voters "have the right to be ruled by anyone they choose." Id. at 256. On the status of political participatory rights as fundamental or basic rights, see supra note 9 .

17. See id. at 239.

18. This would be another take on the desert-oriented quota-debates, assuming that with regard to elected offices, electoral choices or preferences constitute a candidate's just desert. I do not find this framing of the quota-debate very fruitful in general-but see Anita L. Allen, Was I Entitled or Should I Apologize? Affirmative Action Going Forward, 15 J. EтнICs 253 (2011); Luke C. Harris, Contesting the Ambivalence and Hostility to Affirmative Action within the Black Community, in A Companion to African-American Philosophy 324 (Tommy Lee Lott \& John P. Pittman eds., 2003). Further, I find this framing especially out of place for the discussion of electoral quotas, since it is hard to see-at least on liberal democratic assumptions-how anyone could deserve to exercise political authority. Voters may have a pro tanto right to be governed by those they elect and even to nominate candidates for election, but this right again seems to resist plausible formulations in the language of "desert." A more helpful framing of this debate concerns what features should be relevant to candidate selection-where relevance could include several factors, just as in selection on the employment market. See Carl Cohen \& James P. Sterba, Affirmative Action and Racial Preference: A Debate (2003), at 25. On candidate selection, see Jane Mansbridge, A "Selection Model" of Political Representation, 17 J. Pol. Phil. 369 (2009). 
right to stand for election. Proponents of quotas may concede that output quotas restrict the pro tanto scope of political participatory rights. But other rights and principles also apply to the design of legislative assemblies or representative institutions more generally-and these latter rights and principles should be prioritized, in their view, over the pro tanto political participatory rights concerned.

Procedural quotas typically require political parties to establish candidate nomination lists that have a certain minimum ratio of (leading) positions allocated to members of a disadvantaged group. ${ }^{19}$ For example, at most every second candidate or 70 percent of the candidates altogether should be of the same gender. Procedural quotas interfere with the electoral procedure at an earlier stage than output quotas: they preempt situations in which candidates are elected but cannot take their seats. Thus voters' choices as expressed through their votes are never overridden. However, this is little solace to opponents of quotas, who assume that voters have a right to vote into the legislative assembly whomever they prefer, and aspiring candidates have a right to occupy legislative mandates if voters would choose them given an unconstrained choice set. Again, proponents of procedural quotas may even grant these claims concerning the pro tanto scope of political participatory rights, and disagree with opponents only on the relative weight of political participatory rights vis-à-vis other rights and principles that should bear on the design of the electoral system and procedure. $^{20}$

Input quotas. Output and procedural quotas apply to political parties once they engage with the electoral procedure. Input quotas apply at an even earlier stage: they interfere with the internal life of political parties, going to "the very core of the relationship between voters, parties and representatives." ${ }^{21}$ Such measures may prescribe, for instance, gender constraints on the composition of party leadership bodies, or require party bylaws to regulate internal candidate nomination procedures in such a way that would guarantee gender equality among the candidates that the party nominates-i.e., establishes as "inputs"-for elections. For example, the Federal Constitution of Mexico prescribes that political parties shall develop "rules to ensure gender parity in the nomination of candidates in federal and

19. For a survey, see Mona Lena Krook, Reforming Representation: The Diffusion of Candidate Gender Quotas Worldwide, 2 Pol. \& Gender 303 (2006).

20. Candidacy rules for the Parliament of India provide an example of what may appear as output quotas, technically speaking: a significant number of seats (constituencies) are reserved for candidates who are members of so-called Scheduled Castes and Scheduled Tribes. In fact, these are procedural quotas, as they interfere with the choice set available to voters, rather than directly imposing quotas on the electoral outcome. See The Representation of the People Act, Act No. 43 of 1951, $\$ 4$ (a)-(c). Another, overtly procedural, quota is applied, for example, in Portugal, where more than two consecutive candidates of the same sex are prohibited to appear on lists in multimember constituencies. Lei Orgânica n. 3/2006 (Lei da paridade), Diário da República n. ${ }^{\circ}$ 160/2006, Série I de 2006-08-21 (Act No. 3 of 2006 on Equality) art. 2, §2 (Port.).

21. Dahlerup, supra note 12 , at 10 . 
local congressional elections." ${ }^{22}$ Input quotas are widely seen as infringing on the fundamental or basic political participatory rights of voters and candidates just as output and procedural quotas do. Additionally, however, input quotas may also be seen as interfering with internal party life-and hence, as infringing on the freedom to associate in the institutional form of political parties. ${ }^{23}$

Output quotas, procedural quotas, and input quotas thus seem to interfere with fundamental or basic political participatory rights, on the External Restriction Approach, though in different ways and with varying levels of severity. The right to vote, the right to stand for election, and the right to free political association all seem to be implicated: these political participatory rights, justifiably or not, are restricted by electoral quotas on this approach. In the next section, I will review what I take to be the best-though by no means the only possible-justification for such alleged infringements.

\section{A POLITICAL EGALITARIAN JUSTIFICATION FOR AFFIRMATIVE ACTION QUOTAS}

In this paper, I propose a political egalitarian grounding of electoral quotas. Electoral quotas, on this account, are affirmative action measures that aim to ensure citizens' equal opportunities in political participation against a background of politically arbitrary classifications. ${ }^{24}$ More precisely, electoral quotas can be justified insofar as they serve to neutralize inequalities of opportunity to exert political influence ${ }^{25}$ through the exercise of political

22. Constitución Politica de los Estados Unidos Mexicanos, CPEUM, Diario Oficial de la Federación [DOF] 05-02-1917, últimas reformas DOF 28-05-2021, art. 41 (Mex.). English translation is credited to International Institute for Democracy and Electoral Assistance (IDEA), Mexico, Gender Quotas Database (2020), https://www.idea.int/data-tools/data/gender-quotas/country-view/220/35. See also AtLas of Electoral Gender Quotas, supra note 1, on electoral gender quotas in Mexico.

23. Regarding gender input quotas, Dahlerup aptly observes that "one may ask whether the limits imposed by quotas do not restrict the free scope of the party leadership more than that of voters. Seen from a different perspective, gender quotas may in fact expand the choices of voters." Dahlerup, supra note 12, at 11. Quotas may indeed allow some aspirants whom voters would gladly nominate or vote for access to candidacy, despite the resistance of party leadership to the candidacy of these aspirants. Yet input quotas may also result in the exclusion of some aspirants from candidacy despite that voters would gladly nominate or vote for them. Note, further, that some related evidence suggests that not all kinds of quotas are used for all disadvantaged groups with the same frequency. Mala Htun shows that ethnic electoral quotas are typically output quotas, whereas gender electoral quotas are typically procedural or input quotas (in my terminology), and she explains this by emphasizing that the latter "suit groups whose boundaries crosscut partisan divisions." Mala Htun, Is Gender Like Ethnicity? The Political Representation of Identity Groups, 2 PERSP. ON POL. 439, 439 (2004). Which groups fit that description depends on the political context.

24. I will use "citizens" interchangeably with "members of the political community," for expository ease. This should not be understood as taking any substantive position on the boundaries of the demos.

25. Cf. Harry Brighouse, Egalitarianism and Equal Availability of Political Influence, 4 J. POL. PHIL. 118 (1996). 
participatory rights, when such inequalities are responsive to politically arbitrary characteristics. In this section, I present and elaborate on this political egalitarian grounding (justificatory aim) of electoral quotas. However, the political egalitarian account is completed later, in Section VI, with a discussion of when this aim should be served specifically by quotas rather than other measures.

Politically arbitrary characteristics are such features of a citizen that are not legitimate sources of relative political advantage or disadvantage in a democratic society. ${ }^{26}$ For example, gender identity or racial or ethnic background per se is not a legitimate source of relative disadvantage in exerting political influence. ${ }^{27}$ I do not stipulate here any particular account of what makes a characteristic politically arbitrary. I merely assume what I take to be uncontroversial: namely, that there is a principled distinction between politically arbitrary and nonarbitrary characteristics such that only the arbitrary ones are illegitimate sources of inequalities of opportunity in exerting political influence. $^{28}$

But what should be the role of politically arbitrary characteristics in triggering the affirmative action justification of electoral quotas? Inequalities of opportunity in political influence trigger the affirmative action justification of electoral quotas when such inequalities are responsive to politically arbitrary characteristics. What I mean by responsiveness is captured by the following counterfactual: if citizens with a politically arbitrary characteristic and worse opportunities to exert political influence than other citizens did not have the politically arbitrary characteristic, they would not have worse opportunities either. Responsiveness requires more than mere correlation with a politically arbitrary characteristic, but it does not necessarily

26. It is only in this sense that these characteristics are politically "arbitrary." In the overwhelming majority of cases, or arguably in all cases, the fact that such characteristics are sources of political (dis)advantage is a product of political history-and the political choices that constitute that history are subject to moral criticism. I thank Adom Getachew for pressing me to clarify this.

27. In practice, who should determine, and through what procedure, the members of which groups should be the beneficiaries of electoral quotas based on the criteria to be laid out in this section? A necessary condition for the authority of any such procedure is its sufficient responsiveness to empirical social scientific evidence. Judicial bodies as well as more politically balanced commissions of the political branches could satisfy this condition. In India, for example, where "educationally and socially backward" groups are beneficiaries of affirmative action measures, a politically appointed fact-finding commission-with members of various qualifications - must provide ordinarily binding advice to the central government as to whether a group qualifies as belonging to this category at a given point in time. National Commission for Backward Classes Act, No. 27 of $1993 \S \S 3$, 9; cf. India Const. art. 338, §5, 340. I thank an anonymous reviewer for raising this question.

28. Further, I assume that what counts as politically arbitrary is, at least to some extent, contingent on the particular political context. I also assume, though, that there are moral constraints on what group identities may be politicized in a liberal democracy, as much as there are moral requirements on what group identities should be allowed to be politicized. For examples of morally questionable constitutional bans on politicizing certain group identities, along religious or ethnic lines, see Nenad Stojanović, Discrimination and Politics, in The Routledge Handbook of the Ethics of Discrimination 348, 352 (Kasper Lippert-Rasmussen ed., 2018). 
require that the political inequality in question be caused by a politically arbitrary characteristic. ${ }^{29}$

Consider, for example, cases in which past or present wrongs-e.g., racist public policy or social practices-that track a politically arbitrary featuree.g., race-cause present-day inequalities of opportunity. In such cases, if citizens with worse opportunities to exert political influence did not have the politically arbitrary characteristic, they would not have worse opportunities. Hence, these inequalities of opportunity to exert political influence are responsive to the politically arbitrary characteristic. This makes such present-day inequalities objectionable, and triggers the affirmative action justification for electoral quotas based on my account.

However, imagine that past wrongs affect political equality in a much more complicated way (as they are often bound to). For instance, educational attainment increases one's opportunities to exert political influence, but past discrimination-gender-based, race-based, or based on any other politically arbitrary characteristic-may well (and often does) cause presentday inequalities in educational attainment, in turn. ${ }^{30}$ In such cases too, inequalities of opportunity to exert political influence correlate with a politically arbitrary characteristic: gender or race. But these present-day inequalities of opportunity are not necessarily responsive to the politically arbitrary characteristic. It is not necessarily the case, in this example, that those with lower educational attainment would have better opportunities to exert political influence if they were, say, men instead of women, or if they belonged to the racial majority instead of a racial minority discriminated against. These unequal opportunities correlate with race or gender. Yet if they were not responsive to these politically arbitrary characteristics, then they would not trigger the affirmative action justification for electoral quotas based on my account ${ }^{31}$ — unless (and by virtue of the fact that) educational attainment itself is a politically arbitrary characteristic that they are responsive to. ${ }^{32}$

29. "Not necessarily," as the relationship between counterfactuals and causation depends on one's theory of causation. Most influentially, David Lewis argues for a counterfactual analysis of causation. David Lewis, Causation, 70 J. PHIL. 556 (1973). For an example of the vast critical literature, see Ned Hall, Two Concepts of Causation, in Causation and Counterfactuals 225 (John David Collins, Edward J. Hall \& L. A. Paul eds., 2004).

30. I am grateful to an anonymous reviewer for inviting me to reflect on this example. Whether opportunities to exert political influence are responsive to race, gender, etc., in any particular real-life version of this example is, of course, an empirical matter.

31. Relying on responsiveness to identify cases in which politically arbitrary characteristics trigger affirmative action provides us with an account of political equality that is hardly very radical. I consider this a dialectical advantage because the paper can thus show the path to justifying electoral quotas even on less radical grounds-even if the justification thus applies to a limited number of cases. On a more radical understanding of political equality-e.g., if all inequalities of opportunity correlated with politically arbitrary characteristics trigger affirmative action-the case for electoral quotas may be even stronger. Nothing in the rest of my argument depends on whether the more or less radical account is assumed.

32. Note that if one classifies educational attainment as a politically arbitrary characteristic, one need not deny either that educational attainment-either on an individual or on a 
Some distinctive characteristics of this justification of electoral quotas are worth pointing out. First, it is nonremedial, i.e., synchronic rather than diachronic in its ultimate concern. Its objective is not to compensate groups or individual members of groups for past injustices. ${ }^{33}$ History is only relevant to this justification insofar as it played a causally significant role in creating and maintaining present-day injustices. Inequalities of opportunity to exercise political influence that are responsive to politically arbitrary characteristics are unjust, irrespective of what historical forces may have given rise to these inequalities. ${ }^{34}$ The normative telos of electoral quotas is to achieve and maintain a state of affairs that is free from objectionable inequalities of opportunity so understood. Political equality requires, inter alia, that there be no such inequalities between members of a political community. Thus, the justification offered here is not backward-looking but forward-looking. ${ }^{35}$ It also follows from this account that it is somewhat of a misnomer to treat electoral quotas as a means to achieve "equality of result" as opposed to "equality of opportunity." 36 Quotas are means to achieve or maintain equality of opportunity within a specific domain-which in turn is necessary for political equality, properly understood. In other words, equality of opportunity-at least on my account-just is the result to be achieved by means of electoral quotas.

Second, my political egalitarian account of electoral quotas is domain-specific rather than domain-general: it applies specifically to equality of opportunity in exerting political influence through the exercise of political participatory rights - as opposed to equality of opportunity in general, or across different spheres of life. My account does not justify affirmative action

collective level-may improve the quality of political participation and decision-making, or even that it is morally desirable that educational attainment should increase one's political influence in absolute terms. The political arbitrariness of educational attainment implies, instead, that it is objectionable if inequalities of opportunities to exert political influence are responsive to educational attainment. Further, even if educational attainment is not assumed to be a politically arbitrary characteristic, yet it mediates between a politically arbitrary characteristic and inequalities of opportunity to exert political influence in the way described in the body of the text, this still quite obviously constitutes an injustice-but one of educational rather than political inequality.

33. Cf. Stephen Kershnar, Justice for the Past (2004); George Hull, Affirmative Action and the Choice of Amends, 43 PHILOSOPHIA 113 (2015). Tarunabh Khaitan characterizes affirmative action as "non-remedial" in a somewhat different sense: he understands it as "wrong-insensitive," i.e., "the person adopting the measure need not herself have done anything wrongful." TARUNABH Khaitan, A Theory of Discrimination Law (2015), at 215. However, this is also true about electoral quotas on my account. The ultimately nondiachronic concern explains why my account is wrong-insensitive.

34. This is not to deny that historical injustices may exacerbate the injustice concerned. I merely claim here that the justification I am proposing does not rely on the assumption that the objectionably unequal opportunities are unjust because they result from historical injustices.

35. For this reason, the justification goes beyond merely counterbalancing the effects of intentional "racial vote dilution." Stojanović, supra note 28, at 351-352.

36. See, e.g., Dahlerup, supra note 12, at 9. 
measures in other domains-such as housing, employment, schooling, etc. ${ }^{37}$ Nor does it deny the moral desirability, permissibility, or even requirement of affirmative action measures-among them, even quotas-in those spheres of life. Domain-specificity merely means that my justification for affirmative action in the form of electoral quotas does not directly supply at once a justification for affirmative action measures-among them, quotas-in other spheres.

Third, my account is politically outcome-neutral. Electoral quotas can affect political outcomes. For example, gender-based electoral quotas may result in reduced spending on defense and sports, or increased spending on education and health care. ${ }^{38}$ Yet my account is not motivated by the (moral) desirability of any particular substantive democratic outcome. Nor does this account aim to establish racial or gender justice tout court or substantive justice more broadly construed by means of electoral quotas. Further, this account does not aim to remove certain political views from the political agenda of democratic institutions or to sideline them therein-such as misogynist, racist, or other extremist views-even though it may have that (desirable) effect if widely applied. Electoral quotas do not serve, on this account, to tweak democratic outcomes, but to realize —in specific circumstances-political equality and hence a just democratic procedure.

Fourth and finally, my account of electoral quotas is empirically contingent on background conditions. It justifies electoral quotas to the point in time and to the extent that they are necessary to realize equal opportunity in exerting political influence through the exercise of political participatory rights. ${ }^{39} \mathrm{I}$ will discuss this feature of my account in more detail in Section VI.

But what is the relationship between the values underpinning electoral quotas, on this account, and the values underpinning the political participatory rights that electoral quotas seem to interfere with? This is what I will discuss in the next section, reconstructing the External Restriction Approach and contrasting it with a novel alternative: the Internal Restriction Approach.

37. Cf. Hanoch Dagan \& Avihay Dorfman, Just Relationships, 116 Colum. L. Rev. 1395 (2016).

38. See Gretchen Bauer, 'Let There Be a Balance': Women in African Parliaments, 10 PoL. STUd. Rev. 370 (2012); Aimee Chin \& Nishith Prakash, The Redistributive Effects of Political Reservation for Minorities: Evidence from India, 96 J. Dev. Econ. 265 (2011); Sylvia Tamale, Introducing Quotas in Africa: Discourse and Legal Reform in Uganda (2003), https://citeseerx.ist.psu.edu/view$\mathrm{doc} /$ download?doi=10.1.1.460.5666\&rep=rep1\&type=pdf; Georgina Waylen, Women's Mobilization and Gender Outcomes in Transitions to Democracy: The Case of South Africa, 40 ComP. Pol. STUd. 521 (2007).

39. Cf., e.g., Inter-Parliamentary Council, Plan of Action to Correct Present Imbalances in the Participation of Men and Women in Political Life, 154th Sess. (Mar. 26, 1994), which sees genderrelated affirmative action measures as "strictly interim." However, some Nordic countries introduced gender electoral quotas only after women gained a considerable proportion of the legislative assembly seats. Dahlerup, supra note 12, at 7, 18. See discussion in Section VI, infra. 


\section{THE NORMATIVE ROOT OF ELECTORAL QUOTAS: EXTERNAL VS. INTERNAL TO THE GROUNDS OF POLITICAL PARTICIPATORY RIGHTS}

In this section, I contrast two views concerning the normative relationship between electoral quotas and political participatory rights: the External Restriction Approach-the more received view-and its overlooked methodological alternative, the Internal Restriction Approach. I do not aim here to offer a critique of the External Restriction Approach. Instead, I aim to establish the Internal Restriction Approach as a distinct and attractive alternative available to those committed to a political egalitarian account of political participatory rights.

Before presenting its alternative, let me reconstruct the received view: the External Restriction Approach to the relationship between political participatory rights - the right to vote, the right to stand for election, and the right to free political association in the form of political parties-and electoral quotas. This approach justifies the pro tanto scope of the former rights by reference to one set of underlying values, and justifies electoral quotas by reference to a different set of underlying values. Political participatory rights may be justified, for example, on autonomy or individual self-determination-related grounds, ${ }^{40}$ as well as on collective selfdetermination grounds, ${ }^{41}$ whereas electoral quotas are justified on egalitarian grounds. ${ }^{42}$ In this sense, the justificatory grounds of electoral quotas are external to the justificatory grounds of political participatory rights-whatever the latter grounds exactly are. Electoral quotas impose restrictions on the pro tanto scope of political participatory rights, and hence raise a characteristic question of justification: Why and to what extent should we allow these political rights to be restricted? On this account, quotas always raise a question of practical value conflict (or, potentially, even a conflict of rights): If the values grounding political participatory rights and the values underpinning electoral quotas cannot both be fully realized, when and how far could or should we restrict political participatory rights for the sake of realizing the values that justify electoral quotas? This value-conflict is resolved by means of a balancing exercise. ${ }^{43}$

40. See, e.g., Kai Möller, The Global Model of Constitutional Rights (2012), at 35-40, 91, 94; cf. Carol C. Gould, Rethinking Democracy: Freedom and Social Cooperation in Politics, Economy, and Society (1990); Christian F. Rostbøll, The Non-instrumental Value of Democracy: The Freedom Argument, 22 Constellations 267 (2015).

41. See, e.g., Margaret Moore, The Moral Value of Collective Self-Determination and the Ethics of Secession, 50 J. Soc. PhiL. 620 (2019).

42. I would like to thank an anonymous reviewer for pressing me to recognize the diversity of grounds for political participatory rights that the External Restriction Approach may rely on.

43. "Balancing" may be interpreted in a broader or a narrower sense. The broader sense would involve any act of resolving a practical value conflict, regardless of how conflicting values relate to each other: one could serve as a constraint on the other, exclude the consideration of the other value or right, or undercut reasons flowing from the other value or right, and so forth. The narrower sense involves two commensurable values that apply symmetrically to a 
Both supporters and opponents of electoral quotas may be committed to the External Restriction Approach. They may disagree on factual matters (e.g., whether electoral quotas are necessary or effective as a means to realize political equality), or they may disagree on moral questions (chiefly, whether the value realized by electoral quotas should outweigh the value underlying political rights, or the other way around). Still, as long as the debate is framed in terms of moral balancing, the External Restriction Approach reigns. It need not, as I will show soon. This approach does not exhaust the logical space for the potential relationships between political participatory rights and electoral quotas; as I will argue, it has a morally attractive alternative. In the rest of this section, I aim to articulate this alternative-viz, the Internal Restriction Approach-and argue for its moral appeal.

The Internal Restriction Approach relies on broadly political egalitarian assumptions: it assumes that the existence and distribution of political participatory rights have an ultimately social or political egalitarian justification. ${ }^{44}$ There is, of course, considerable disagreement over the details of such an egalitarian account, and I have no space in this paper to engage with these controversies, or to defend the political egalitarian foundations of political participatory rights. My argument for the Internal Restriction Approach is conditional on a particular political egalitarian grounding of political participatory rights.

Political equality entails at least two kinds of moral requirements: one concerning the distribution of political power, ${ }^{45}$ and another one concerning the expressive significance of equal political status. ${ }^{46}$ I will refer to these, respectively, as the material and the expressive requirements. ${ }^{47}$ The material requirement, in the version I rely on, requires that no member of the political community should have worse opportunities to exert political influence through the exercise of political participatory rights than other members when such inequalities are responsive to politically arbitrary group membership. ${ }^{48}$ The expressive requirement, in the version I rely on,

given situation but cannot be fully realized at the same time. Hence, balancing requires a judgment of the relative weight of the values or rights in conflict. The External Restriction Approach to the quota debate relies on the narrower sense of "balancing." Thanks are due to Zoltán Miklósi for pressing me to clarify this.

44. See, e.g., Brighouse, supra note 25; cf., more recently, Niko Kolodny, Rule over None II: Social Equality and the Justification of Democracy, 42 PHIL. \& Pub. Afrs. 287 (2014); Daniel Viehoff, Democratic Equality and Political Authority, 42 Phil. \& Pub. Affs. 337 (2014); James Lindley Wilson, Democratic Equality (2019).

45. See, e.g., Brighouse, supra note 25.

46. On the symbolic significance of disenfranchisement, see, e.g., Ronald Dworkin, Sovereign Virtue: The Theory and Practice of Equality (2000), at 187.

47. Here I follow the terminology introduced in Attila Mráz, Disenfranchisement and the Capacity/Equality Puzzle: Why Disenfranchise Children but Not Adults Living with Cognitive Disabilities, 7 Moral Phil. \& Pol. 255, 267-268 (2020).

48. Cf. Brighouse, supra note 25, at 119; Kolodny, supra note 44, at 289. While Brighouse talks about "availability," I will use "opportunity." Brighouse does not mean these two concepts to be interchangeable, but their difference is immaterial for my argument. Brighouse, supra note 25. 
requires that "no member of the political community should be subject to any treatment by the community that expresses their moral inequality or lesser worth as members of the political community." 49 These requirements serve to ensure that our moral and political status as one another's equals is compatible with the existence of political authority. The existence and proper distribution of political participatory rights-chiefly, the right to vote, the right to stand for election, and the right to associate in the form of political parties-are, in turn, instrumentally and constitutively necessary to meet these requirements. But then, political participatory rights are meant to realize, on the one hand, the very same underlying value of material political equality that grounds electoral quotas on the account offered in Section II. On the other hand, political participatory rights are meant to realize expressive political equality as well, which does not ground electoral quotas on my account, but it can also be furthered by such quotas-as I will show below.

Let me first elaborate on how the material requirement of political equality, given its concern with equal opportunity to exert political influence, supports the Internal Restriction Approach, showing electoral quotas to be "internal restrictions" or inherent limits on political participatory rights. I will illustrate this by critically engaging with a political egalitarian account of political participatory rights-namely, Andrew Rehfeld's theory ${ }^{50}$ which is opposed to quotas seen as restrictions on these rights. My aim is not to criticize Rehfeld's theory, but to show how seeing both these rights and electoral quotas as realizing the material requirement of political equality can shed a different light on the justifiability of electoral quotas.

In Rehfeld's view, political equality requires that " $[\mathrm{t}]$ he right to vote must be paired with a right to an unconstrained choice for office." 51 That is, voters' political participatory rights must include a pro tanto entitlement against any measure that would reduce voters' choice set relative to a completely unrestrained one. Further, Rehfeld argues, "qualifications for office"-among which he counts electoral quotas-"always violate the right to run for office." 52 Candidates' (and aspiring candidates') political participatory rights must include, then, a pro tanto entitlement against any measure that would make it less probable for one to successfully run for office than it is for anyone else, except if such differential probabilities reflect voters' judgments. ${ }^{53}$

However, first, there is no reason to assume that voters' pro tanto political participatory rights entail a right to an unconstrained choice set of

49. Mráz, supra note 47, at 268; cf. Charles R. Beitz, Political Equality: An Essay in Democratic Theory (1989), at 155; Thomas Christiano, The Constitution of Equality: Democratic Authority and Its Limits (2008), at 71.

50. Rehfeld, supra note 4.

51. Id. at 258 (emphasis added).

52. Id. at 264. Rehfeld uses the term "violation" in the sense I use "restriction" or "interference," meaning a potentially justifiable but pro tanto objectionable right restriction.

53. Id. at 262. 
candidates. Instead, the material requirement of political equality should entitle voters to a choice set that is only compatible with unequal opportunities to exert political influence through the exercise of political participatory rights that are not responsive to politically arbitrary characteristics. Real-life inequalities heavily determine opportunities for candidate nomination not only due to differences in wealth and social and educational capital, but also through so-called "reaction qualifications." ${ }^{\text {" Parties judge }}$ potential candidates based on their perceived electability, and nominate candidates whom voters-given their actual preferences-want to see on the ballot. Hence, voters' prejudices as to members of which groups they see as capable candidates are bound to affect the "unconstrained" choice set that voters get to choose from. Insisting on an unconstrained choice set reinforces objectionable inequalities of opportunity in exerting political influence responsive to politically arbitrary group membership. ${ }^{55}$ Therefore, the appropriate choice set is not the unconstrained one based on voters' actual preferences, but a counterfactual one that attempts to counterbalance such inequalities. This is the choice set that realizes the material requirement of political equality. Quota measures justified on my account serve to realize and maintain this adequate choice set, and hence do not restrict the pro tanto scope of voters' political participatory rights as specified on political egalitarian grounds.

Second, for the same reason, candidates and aspiring candidates' political participatory rights, if justified on political egalitarian grounds, cannot entitle right-holders to the probabilities of success in electoral competition that voters' actual preferences warrant. Such preferences are partly shaped by racist, sexist, and otherwise morally tainted preferences. Insofar as probabilities of winning an office are a result of such preferences that contribute to objectionable inequalities of opportunity in exerting political influence through the exercise of political participatory rights, the material requirement of political equality demands that such probabilities be readjusted, and not solidified. Quota measures—when justified-carry out this readjustment of probabilities, and hence they do not restrict candidates' and aspiring candidates' pro tanto political participatory rights. Quite on the contrary, the pro tanto scope of these rights does not extend to immunity against such readjustments.

The political egalitarian revision of unconstrained choice sets and probabilities of success does not aim to correct, in any sense, voters' preferences and judgments. It merely assumes that voters' preferences and judgments are to be respected due to our commitment to, and only within the limits

54. Alan Wertheimer, Jobs, Qualifications, and Preferences, 94 Eтнics 99 (1983).

55. Cf. Kathleen Dolan's recent empirical account of the significance of gender stereotypes for voters' choices in US elections. Kathleen A. Dolan, When Does Gender Matter? Women Candidates and Gender Stereotypes in American Elections (2014). Dolan argues that gender stereotypes actually have a limited role in explaining voters' decisions in US elections. This may be a context-specific finding, however. 
of, political equality. Voters should have the right to exercise wide discretion in selecting candidates, and candidates should likewise be entitled to compete for office based on voters' discretionary judgments. Yet voters' choice set, and their discretion as the ultimate determinant of candidates' success, may and sometimes should be constrained by the same political egalitarian considerations that ground, as I assume, their political participatory rights.

The above understanding of the role of material political equality in an account of political participatory rights allows us to approach the relationship between the values underlying political participatory rights and those underlying electoral quotas in an entirely different way than the External Restriction Approach. This alternative understanding supports the Internal Restriction Approach, which conjectures that the justification of both political participatory rights and electoral quotas-as a form of affirmative action-have the same normative grounds. Not only electoral quotas but also political participatory rights ultimately serve to establish political equality by ensuring that objectionable inequalities of opportunity in exerting political influence are neutralized. To the extent that political participatory rights do not serve to realize political equality, but are rather instrumental to upsetting political equality, we have no reason to value or protect them as basic or fundamental rights at all. For example, if the broad pro tanto scope of the right to stand for election-as Rehfeld conjectures its scope-resulted in women being systematically excluded from political representation, or if the pro tanto scope of the right to associate in political parties included the liberty to exclude Roma citizens from party membership, thereby creating or exacerbating unequal opportunities for Roma citizens to exert political influence, it would be unjustified to extend the pro tanto scope of political participatory rights as far as to cover such conduct in the first place. In other words, the same conditions that justify the imposition of electoral quotas at once undercut the justification for a broad-i.e., quota-free-pro tanto scope of political participatory rights.

The Internal Restriction Approach also shows how justified electoral quotas do not compromise the expressive requirement of political equalitythe other political egalitarian ground of political participatory rightseither. Electoral quotas set at the appropriate level to neutralize inequalities of opportunity responsive to politically arbitrary group membership do not express the lesser worth of those members of the political community whose interests they adversely affect. ${ }^{56}$ Moreover, affirmative action measures in general, and electoral quota measures especially, can expresswhen justified-that "public institutions are genuinely representative and

56. Following Deborah Hellman, I distinguish between what a treatment, practice, or regulation expresses, and what it is taken to express by those whom it negatively affects. DEBORAH Hellman, When Is Discrimination Wrong? (2008), at 60-79. If those whom it negatively affects interpret an electoral quota as expressing their inferior worth, this is neither necessary nor sufficient to establish that this is indeed what the quota measure expresses. 
participative. ${ }^{57}$ Hence, when justified (albeit on grounds of material political equality), not only do electoral quotas not express the inferior worth of any member of the political community, but they also positively reaffirm the equal worth of some of its members. Thus, justified electoral quotas collaterally contribute to expressive political equality too. Yet again, we find that political participatory rights do not guarantee, not even pro tanto, a quotafree electoral environment-not even insofar as they serve to realize the expressive requirement of political equality. ${ }^{58}$

On my account of electoral quotas, then, properly justified quota measures do not impose restrictions on the pro tanto scope of political participatory rights, taking both the material and expressive grounds of the latter into account. Instead, the apparent restrictions that quotas seem to impose on political participatory rights are internal to the justification of these rights in the following sense. What appears to be a right-restriction is in fact a mere illusion of a restriction. The pro tanto scope of the rights in question does not extend to an opportunity or conduct that these rights are (mistakenly) seen as covering — not even if examined in isolation from any values conflicting with these rights. Consequently, there is nothing to restrict, strictly speaking, in the given contexts. No pro tanto right is overridden or outweighed by any weightier right or other moral consideration, all things considered. What we witness, instead, is merely the more precise specification of the pro tanto scope of political participatory rights in light of their justification. ${ }^{59}$ What appears at first sight to be within the

57. KHaItan, supra note 33, at 235-236.

58. An important caveat: we could not reach the same conclusion if we did not merely apply electoral quotas to neutralize inequalities of opportunity to exert political influence but also compromised the "one person, one vote" principle in pursuit of the same goal. Providing women with two votes, for instance, could neutralize the relevant inequalities of opportunity just as well as electoral quotas do, in some circumstances. But this solution would, I presume, express the inferior worth of men as members of the political community-and hence would interfere with their political participatory rights insofar as the latter serve to realize the expressive requirement of political equality. This expressive implication is further strengthened if such a solution is unnecessary to achieve the relevant affirmative action goals, see infra Section VI. Cf. Gray v. Sanders, 372 U.S. 368, 381 (1963) (finding that the conception of political equality inherent in the US Constitution requires adherence to the "one person, one vote" principle).

59. Cf. Gardbaum's description of internal limits on constitutional rights: "Internal limits on rights address the issue of whether a constitutional right is implicated in a given situation in the first place. That is, they concern the meaning and scope-the definition-of a constitutional right. Thus, for example, does the constitutional right to free speech include car bombing the president as an expressive act of political dissent? The answer is no, which amounts to an internal limit on the right to free speech: There is no such constitutional right in the first place, and hence, never the need to justify infringing it." Gardbaum, supra note 5, at 801; see also Stephen Gardbaum, The Structure and Scope of Constitutional Rights, in ComparaTrve Constitutional Law 387, 388 (Tom Ginsburg \& Rosalind Dixon eds., 2011). However, while "definition" is a helpful term to contrast with infringement or restriction, it may mistakenly suggest that justifying internal restrictions is a conceptual rather than substantive matter. This clearly does not hold for moral rights, and not even for legal rights when their specification involves any teleological interpretation of positive law. Defining the pro tanto scope of a right requires, in most cases, substantive normative reasoning based on the justificatory ground 
pro tanto scope of these rights turns out, on reflection, not to be covered by these rights at all. ${ }^{60}$ This sheds a new light on the relationship between political participatory rights and electoral quotas too; this different approach to their relationship is at the core of what I refer to as the Internal Restriction Approach.

On the Internal Restriction Approach, the pro tanto scope of political participatory rights ends exactly where the extension of justified electoral quota measures begins. Political participatory rights do not extend as far as they are thought to extend-and electoral quotas are not as difficult to justify as they are thought to be. The same underlying principle can justify, depending on a given context, either extensive political participatory rights (that do not allow for quotas), or electoral quotas jointly with political participatory rights of a more restricted pro tanto scope-but never both an extensive pro tanto scope of political participatory rights and electoral quotas restricting them. The possibility of a practical conflict between political participatory rights and electoral quotas, as justified on the same political egalitarian grounds, is thus preempted. ${ }^{61}$ Hence, the Internal Restriction Approach to the relationship between political participatory rights and electoral quotas provides an error-theoretical justification of electoral quotas as merely apparent right-restrictions.

\section{TWO IMPLICATIONS OF THE INTERNAL RESTRICTION APPROACH}

The Internal Restriction Approach to the relationship between political participatory rights and electoral quotas may be of philosophical interest in itself, as it provides a novel approach to justifying (apparent)

of that right. In Aharon Barak's words, "[t] he question is what is the proper reach of the right, considering the factors at the basis of the right." Aharon Barak, Proportionality: Constitutional Rights and Their Limitations (2012), at 36. Hence, I prefer the term "specification" rather than "definition" as a more accurate designation of the relevant substantive normative reasoning at work here. Note, finally, that Justice Barak objects to Gardbaum's use of the term "internal limitations," and hence would likely object to my term "internal restriction" no less. Writing about constitutional provisions determining the scope of a right, Barak insists that such provisions "should not be seen as 'internal limitations' of the right, but rather as 'internal modifiers,' 'internal qualifiers,' or 'demarcations.' . . . The internal qualifier does not limit the constitutional right, but rather defines its scope more narrowly." Id. at 34, 36. While I endorse the aim of properly distinguishing the two kinds of limitation, I take their exact names to be a largely terminological issue.

60. Letsas refers to this illusory scope as the prima facie, as opposed to pro tanto, scope of a right. Letsas, supra note 6 . Note that this use of the qualifier "prima facie" is entirely different from its Rawlsian use in distinguishing prima facie vs. basic rights or liberties; see also supra note 9.

61. Cf. Jeremy Waldron's description of resolving an apparent rights conflict where the exercise of a right asserted by one side is "incompatible with the very idea of the right they are asserting." In his words, in such a case, "[w] hat looked like a brute confrontation between two rival interests, independently understood, turns out to be resolved by considering the internal relation that obtains between our understanding of the respective rights claims." Jeremy Waldron, Rights in Conflict, 99 Eтнісs 503, 518 (1989). 
quota-restrictions on political participatory rights. However, in this section, I want to show that this approach is more than a merely verbal redescription of a conflict of rights or values. Instead, at least two implications of the Internal Restriction Approach substantively distinguish it from the External Restriction Approach: one concerns the role of balancing in justifying electoral quotas, and the other one concerns the deontic status of electoral quotas.

No normative balancing between political participatory rights and electoral quotas

The External Restriction Approach offers a highly contingent account of when electoral quotas may be justified vis-à-vis political participatory rights. What might be the proper balance of conflicting rights and values in one set of factual circumstances may not be the proper balance in another context. ${ }^{62}$ Even if electoral quotas are the only available and effective means to achieve or maintain political equality, the latter may just turn out to be less important to guarantee in some contexts than political participatory rights (when these rights are seen as justified on some other grounds). So, on balancing, political participatory rights may prevail and electoral quotas (or some kinds of them in some contexts at least) may be impermissible. Yet this kind of balancing plays no role in the Internal Restriction Approach, ${ }^{63}$ as there is no conflict of values or rights between political participatory rights and electoral quotas, and hence the former and the latter are not balanced against each other. Justified electoral quotas represent inherent limits on political participatory rights, so it is impossible for the latter to be more important or weighty than the former. Political equality is realized, sometimes through political participatory rights without quotas, and sometimes through political participatory rights with quotas.

However, the justification of electoral quotas is still conditional on socioeconomic circumstances that adversely affect the relevant opportunities of some politically arbitrarily constituted group. Further, the Internal Restriction Approach does not deny that we should aspire for political communities in which electoral quotas become unnecessary to achieve political equality-and thus unjustified. Quotas are in principle temporary. Moreover, the Internal Restriction Approach implies that not only the existence of electoral quotas but also the particular level at which they are set is justified only if necessary to achieve political equality. In Section VI, I will show why electoral quotas are only justified when necessary, on the Internal Restriction Approach.

While the Internal Restriction Approach precludes balancing between political participatory rights and electoral quotas, it does not deny that

62. See BaRAK, supra note 59, at 367-369.

63. Cf. Jacob Weinrib, Dimensions of Dignity: The Theory and Practice of Modern Constitutional LaW (2016), at 215-252. 
electoral quotas-even when justified—set back some individual interests. A man who built up a career of local politics and now wants to enter national politics but cannot get into parliament because no party will put him on the party list is frustrated in his career plans. The members of a political party who want to associate to form a Coalition of Competent Men may correctly register that their aims cannot be realized if political parties must include women in their leadership. The non-Roma woman who wants to run on a party list but whose party chooses a Roma woman instead to fill a position on the list of candidates may understandably complain: she has an interest in being put on the party list. But the Internal Restriction Approach holds that these interests, no doubt real and sometimes weighty, are not protected -or even pro tanto covered-by political participatory rights, and hence that these cases should not be regarded as infringements on the latter rights. As long as the electoral quotas are necessary to neutralize inequalities of opportunity to exert political influence that are responsive to politically arbitrary group membership, political participatory rights are not only not violated, but they are not even restricted or infringed on by introducing or maintaining electoral quotas so justified.

Deontic status: requirement rather than permission

The Internal Restriction Approach does not only establish the permissibility of electoral quotas. Instead, it establishes that-given certain socioeconomic circumstances-quotas as inherent limits on the scope of political participatory rights are, at least, pro tanto required. This is because political equality requires, rather than merely permits, the establishment and maintenance of whatever institutional framework is necessary to realize it. Thus, political equality requires the existence of both political participatory rights and-in some circumstances-electoral quotas.

The External Restriction Approach is more ambiguous in this regard. Some potential versions of it, recognizing a ground for electoral quotas that generates moral (and legal) requirements, might conclude that instituting (some) electoral quotas is required, all things considered, given the proper balancing of the rights in conflict. Yet other versions of the External Restriction Approach may see electoral quotas instead as means to realize values that are optionally pursued by the state, and that may but need not be pursued at the expense of restricting political participatory rights. ${ }^{64}$ Such versions of the External Restriction Approach would only justify a permission to introduce or maintain electoral quotas. Hence, the respective justifications of electoral quotas offered within the External and Internal Restriction Approaches can differ considerably in what is meant by "justifying" electoral quotas. Whereas the External Restriction Approach may justify a mere permission as opposed to a moral (and

64. Cf. Dworkin's arguments for the mere permissibility of affirmative action in higher education admissions. DwORkIN, supra note 46. 
legal) requirement, the Internal Restriction Approach firmly justifies a pro tanto conditional requirement. ${ }^{65}$

However, the Internal Restriction Approach does not establish an all-things-considered moral requirement to introduce or maintain electoral quotas-even when the latter are justified on my account. Defending such a requirement should take either of two routes. First, one could account for all values that are in real (not merely apparent) conflict with political equality and are applicable to the evaluation of electoral quotas-and show that political equality prevails over all the other applicable values. Alternatively, one could show that the apparently diverse values bearing on the evaluation of electoral quotas are all reducible to political equality-and hence all value conflicts between political equality and other values are merely apparent. Both strategies lead to radical conclusions that are extremely hard to establish, to say the least. Yet it is not my ambition to establish either. The Internal Restriction Approach shows that in some circumstances, electoral quotas are pro tanto required, and also that-when electoral quotas are justified on my account-political participatory rights do not ground any countervailing considerations against this pro tanto requirement. While less radical than the two extreme views mentioned, this is still a highly revisionist view of the relationship between electoral quotas and political participatory rights.

The above implications show that the Internal Restriction Approach is not a merely verbal redescription of a value conflict, but it has substantive theoretical and practical consequences for the regulation of electoral quotas in liberal democracies. Before concluding, though, I will now turn to two potential objections to, and a clarification about, the Internal Restriction Approach.

\section{THE NORMATIVE DIVERSITY OF ELECTORAL QUOTAS}

Electoral quotas, one may object, could be justified not only based on the account I briefly outlined in Section II. They may be justified by an aim to compensate for past injustices, ${ }^{66}$ or to promote diversity in legislative assemblies as a guarantee for higher quality deliberation or decisionmaking, ${ }^{67}$ or to ensure that there will be role-models for members of disadvantaged groups, or to offer higher quality representation through better

65. It is no surprise that the legally inspired literature focuses on permissibility. In the recent history of legal challenges against quota measures applied, mostly, in university admissions, defenders of quotas needed and wanted to establish no more than the (legal, as opposed to merely moral) permissibility of applying quota measures. In fact, defenders of affirmative action quite often did not even need to (and could not) defend the legal permissibility of quota measures.

66. See KershnAR, supra note 33; Hull, supra note 33.

67. See Chris Bart \& Gregory McQueen, Why Women Make Better Directors, 8 InT'L J. Bus. Governance \& Ethics 93 (2013); cf. also Jane Mansbridge, Rethinking Representation, 97 Ам. Pol. SCI. Rev. 515 (2003); Mansbridge, supra note 18. 
rapport with constituents or resemblance to them, ${ }^{68}$ among other considerations. ${ }^{69}$ There is no need to examine in detail the merits of these alternative accounts. Even if one of them succeeds in justifying electoral quotas, this reintroduces logical space for genuine value-conflicts (and even conflicts of rights) between political participatory rights and electoral quotas (as means to neutralize unequal opportunities to exert political influence responsive to politically arbitrary characteristics). While the Internal Restriction Approach takes such value conflicts out of the picture, the diversity of the normative reasons offered to justify electoral quotas seems to bring back into the picture all the complexity, theoretical and practical, that comes with an External Restriction Approach. ${ }^{70}$ This, one may object, would question the practical relevance of the Internal Restriction Approach.

In reply, first, consider that political participatory rights-a subset of political rights-are fundamental or basic, ${ }^{71}$ and as such may only be restricted in pursuit of a limited set of adequate aims-mostly, for the sake of realizing other basic rights and political equality. ${ }^{72}$ Yet in this light, not all of the above considerations are adequate aims of restricting basic rights. Compensating for past injustices, increasing the quality of parliamentary deliberation, or providing role models qualify, at best, as derivable from other, adequate aims. Yet as ultimate goals, laudable as they may be, they do not qualify as the right sort of aims for restricting political participatory rights. ${ }^{73}$ This means that most of the justifications of electoral

68. See Carol Bacchi, Arguing for Quotas and Against Quotas: Theoretical Issues, in Women, QuOTAS and Politics 32, 44 (Drude Dahlerup ed., 2006); $c f$. Iris Marion Young, Justice and the Politics of Difference (1990); Anne Phillips, The Politics of Presence (1998); Melissa S. Williams, Voice, Trust, and Memory: Marginalized Groups and the Failings of Liberal Representation (1998); Jane Mansbridge, Should Blacks Represent Blacks and Women Represent Women? A Contingent "Yes", 61 J. PoL. 628 (1999). For the related concept of "descriptive representation" more generally, see Hannah F. Pitkin, The Concept of Representation (1967), at 60-91; cf. Suzanne Dovi, The Good Representative (2007), at 29-34.

69. More generally, on the diversity of reasons offered in favor of affirmative action, see LiPPERT-RASMUSSEN, supra note 10. For an overview of reasons in favor of gender electoral quotas, see Bacchi, supra note 68.

70. Another take on the same objection: even if my account justifies a particular level of electoral quotas (say, a 30 percent procedural gender quota), any quota measure that is set at a higher level-i.e., reserves a higher proportion of places on a party list than what my account justifies for members of the disadvantaged group concerned, say 40 percent instead of 30 percent-reintroduces the value conflict issues insofar as the additional quota level is concerned. In practice, that means-using the same example-reintroducing the value conflict for all party list places thus reserved, since it is impossible to identify which are the places justifiably reserved on my account, and which are the additional ones whose reservation is justified on some other account. (Similar considerations apply, mutatis mutandis, to input and output quotas too.)

71. See, e.g., John Rawls, Political Liberalism (1993), at 294; RaWls, supra note 9, at 111f.

72. See RAWLS, supra note 9, at 111 ; BARAK, supra note 59 , at $245 \mathrm{f}$.

73. E.g., in US constitutional law, diversity is a legitimate aim of affirmative action programs (but not quota measures) in the context of (higher) education admissions only as long as it is conceived as an exercise of academic freedom, i.e., a First Amendment right, but not in and of itself. See Robert Fullinwider, Affirmative Action, The Stanford Encyclopedia of Philosophy 
quotas that involve genuine value conflicts with political participatory rights are bound to fail because the aims quotas serve on these accounts are not adequate to get the balancing against these rights off the ground. Therefore, the normative diversity of justifications that may support electoral quotas does not necessarily create practical complexity or render the account I offered practically irrelevant. On the contrary: in a broadly political egalitarian framework, the alternative justifications that would ground an External Restriction Approach to the relationship between political participatory rights and electoral quotas may often be set aside as unsuccessful, without implying any practical difficulties-and this may leave plenty of space to apply the Internal Restriction Approach.

Second, though, while there is no necessarily complete overlap between the extension of electoral quotas justified on my account, on the one hand, and the extension of electoral quotas justified on different grounds, on the other, the extensional overlap between different justifications is highly consequential. To the extent that a given electoral quota measure is justified by both my account and another justificatory ground-i.e., the justification of electoral quotas is normatively overdetermined-there is no value conflict between political participatory rights and electoral quotas so justified. This is because in such cases of extensional overlap, the egalitarian justification of political participatory rights determines a narrower pro tanto scope for these rights, and hence enables-clears the way, normatively speaking, for-alternative justifications of electoral quotas too. Thus, in cases of extensional overlap, there is a division of labor, so to say, between different justificatory accounts. It is the political egalitarian justification offered in this paper that makes electoral quotas required, but if that justification applies to the given case, the alternative accounts supply additional moral reasons for the electoral quotas that are required on my account. In such cases of extensional overlap, diversity, role-model provision, compensation, etc., can be freely pursued as ultimate goals by the same electoral quota measures that political equality justifies. These considerations need not be balanced against political participatory rights: in such cases of extensional overlap, the former do not restrict the pro tanto scope of the latter. The political egalitarian account has already shown the relevant restrictions on basic political participatory rights to be illusory, in such cases, and hence the question as to whether participatory rights are restricted in pursuit of adequate aims does not even arise. Thanks to the political egalitarian account, then, further justifications of electoral quotas may not only be welcome as additional supporting

(Summer 2018 Edition) (Edward N. Zalta ed., 2018), https://plato.stanford.edu/archives/ sum2018/entries/affirmative-action/, §5; Regents of the University of California v. Bakke, 438 U.S. 265, 312-313, 316 (1978) (finding that an institution of higher education has a First Amendment right to make its own judgments pertaining to the selection of its student body, yet that the attainment of a diverse student body in college admissions may be pursued by means of a race-conscious admissions program but not by means of racial admission quotas). 
(though normatively inert) reasons, but could also shape the regulation of political participatory rights and the electoral system and procedure by providing further legitimate aims of policy-making. Therefore, in extensional overlap cases, my account is not merely compatible with other values grounding alternative justifications for electoral quotas, but it also enables the realization of these other values.

I do not mean to suggest that there is a necessary extensional overlap between different justifications of electoral quotas in terms of the type, level, and temporal scope of the quotas they justify. Genuine value conflicts cannot be wished away. But neither should they be overstated. In this paper, my aim is to show that at least in some cases-and potentially, in a number of significant cases-the Internal Restriction Approach provides a convincing and principled justificatory approach for mandatory electoral quotas, and shows that the latter do not restrict anyone's basic political participatory rights. This may still leave us with genuinely hard cases, some of which include conflicts of basic rights.

\section{THE NECESSITY CONSTRAINT, AFFIRMATIVE ACTION GOALS, AND QUOTAS}

Quotas are typically seen as justified only if they are necessary to achieve the affirmative action goal they are meant to serve, and are set at the level necessary to achieve it-I will refer to this condition as the "necessity constraint." Electoral quotas are justified in those cases when a combination of quotas and political participatory rights are jointly necessary to realize the requirements of political equality-among them, a lack of objectionable inequalities of opportunity in political influence. ${ }^{74}$ Indeed, political movements supporting quotas operate on the assumption that quotas are necessary to achieve that aim. For example, women's movements lost faith in the more incremental equalization of opportunities once they saw existing social practices that reproduce inequalities as instances of active exclusion. ${ }^{75}$ The necessity constraint is not only intuitively plausible, then, but it also enjoys widespread support within political movements promoting gender quotas as "temporary special measures." 76 Further, it is due to the necessity constraint that, as Lippert-Rasmussen aptly remarks, "[g]enerally, quota-based forms of affirmative action are believed to be a stronger form of affirmative action than goal-based forms of affirmative action and, thus,

74. Electoral quotas need not be sufficient or even suitable in themselves to realize that aim, in order to be justified.

75. See Dahlerup, supra note 12, at 8-9.

76. Such "temporary special measures" could potentially include "preferential treatment; targeted recruitment, hiring and promotion; numerical goals connected with time frames; and quota systems." U.N. Committee on the Elimination of Discrimination Against Women (CEDAW) (2004), General Recommendation No. 25, on article 4, paragraph 1, of the Convention on the Elimination of All Forms of Discrimination Against Women, on temporary special measures, II 22, U.N. Doc. A/59/38 (SUPP) (Mar. 18, 2004). 
more difficult to justify." 77 Legal practice partly confirms this intuition, or even exceeds it in the severity of its conclusions: while electoral quota measures are not uncommon in various regions of the world, EU law as well as the federal constitution of the United States arguably prohibit such measures—even though neither prohibits affirmative action more broadly. ${ }^{78} \mathrm{I}$ will resist such a restrictive conclusion, but I do wish to justify the necessity constraint. ${ }^{79}$

The External Restriction Approach to the justification of electoral quotas faces no particular challenge in accounting for the necessity constraint. In a nutshell: it regards electoral quotas as restricting pro tanto political rightsand rights should not be unnecessarily restricted. Although highly intuitive, this justification for the necessity constraint is inconsistent with the Internal Restriction Approach. How can the Internal Restriction Approach justify the necessity constraint if electoral quotas do not restrict political participatory rights, on this account? In this section, I map out two argumentative strategies for justifying the necessity constraint as—respectively-coherent with or following from the Internal Restriction Approach.

The two argumentative strategies are distinguished from each other, yet again, by whether they ground the necessity constraint in a moral requirement external to political equality or internal to it. Let me discuss them in this order. The first strategy—henceforth "the external strategy"-motivates the necessity constraint with a value independent of political equality. One version of this strategy is the External Restriction Approach, with its broad pro tanto scope of political participatory rights. However, other versions of the

77. LipPeRt-Rasmussen, supra note 10 , at 14 . The difference between justifications of affirmative action defined in terms of goals vs. affirmative action measures as quotas is helpfully clarified by Lippert-Rasmussen's conceptual analysis of affirmative action (id. at 13-15; cf. the classification of quota measures in Dahlerup, supra note 12, at 21). Goal-based forms of affirmative action include any kind of policy measure that aims at a particular proportion of whatever scarce positions are distributed to go to disadvantaged candidates. Quota-based forms of affirmative action pursue this aim through a particular means: formally reserving some positions for members of the disadvantaged group in a selection process.

78. Only arguably, as the applicability of EU law to electoral quotas is dubious at best. However, the approach taken by the Court of Justice of the $\mathrm{EU}$ in cases of employment hiring quotas may be seen as suggestive: affirmative action is lawful; quotas are not. See Case C-450/93, Eckhard Kalanke v. Freie Hansestadt Bremen, 1995 E.C.R. I-03051. For further discussion on the EU legal background, see European Union Agency for Fundamental Rights, European Court of Human Rights, \& Council of Europe (Strasbourg), Handbook on European Non-Discrimination Law-2018 Edition (2018), https://data.europa.eu/doi/10.2811/58933, at 72-78. Similar conclusions hold in US constitutional law in the context of university admissions: see Bakke, 438 U.S. 265; cf. Gratz v. Bollinger, 539 U.S. 244 (2003) (finding that race may not be the sole reason for public universities to award applicants 20 percent of the minimum points required for admission).

79. A further role of the necessity constraint is to account for the differential severity of output, procedural, and input quotas mentioned in Section I. On the Internal Restriction Approach account, some forms of electoral quotas are more severe-i.e., more difficult to justify-because they are necessary to achieve political equality in a more limited set of cases than less severe ones. This also implies that when less severe electoral quotas can achieve the same aim, more severe ones cannot be justified. I thank an anonymous reviewer for inviting me to clarify this. Cf. supra note 11. 
external strategy need not make any reference to political participatory rights, even if these versions also ground the necessity constraint in values independent from political equality. For instance, the external strategy may rely on a general substantive principle that we should not set back anyone's interests unless this is necessary in pursuit of any value or ideal. This principle could a fortiori justify the necessity constraint regarding electoral quotas too. Another general, procedural principle may ceteris paribus require political and legal institutions to take into consideration the widest possible range of interests they affect. The rigidity of quota measures in general makes electoral quotas less likely candidates than other affirmative action measures to comply with this requirement. Reserving opportunities for members of a particular group means that a wide range of the interests of those disadvantaged by the given quota measures are excluded from consideration in distributing these opportunities. Hence, such a principle could also justify the necessity constraint. ${ }^{80}$ Further, as Khaitan argues, "in general, strongly distributive direct affirmative action measures should be used as a last resort because they are more likely to imply that the beneficiary group is somehow lacking in talent or industry." ${ }^{81}$ If this is empirically sound, the expressive disadvantage caused by quota measures should ceteris paribus count against them, justifying the necessity constraint.

These versions of the external argumentative strategy are coherent with my main claim that properly justified electoral quotas do not restrict political participatory rights. Yet they justify the necessity constraint despite the lack of any restrictions on pro tanto political rights, rather than by virtue of any such restrictions. These versions save the necessity constraint relying on theoretical resources that lie beyond the account presented here. Electoral quotas are justified, then, in two steps, following the external strategy. The Internal Restriction Approach offers the liberating first step by accounting for electoral quotas as merely apparent restrictions on political rights. Another account-outside the scope of this paper-offers the restrictive second step, justifying the necessity constraint on electoral quotas.

However, a rather different, second argumentative strategy is also available: namely, one that motivates the necessity constraint with normative considerations internal to the ideal of political equality (henceforth: "the internal strategy"). We can distinguish two versions of it: one attempts to justify the constraint by reference to the material requirement of political

80. E.g., Hungarian law allows for affirmative action measures "aimed at the elimination of inequality of opportunities based on an objective assessment of an expressly identified social group" in the election of internal party leadership positions and candidate nominations as regulated by party bylaws, but any such affirmative action measure "shall not exclude the consideration of individual circumstances." 2003. évi CXXV. törvény az egyenlő bánásmódról és az esélyegyenlőség előmozdításáról (Act No. CXXV of 2003 on Equal Treatment and Promotion of Equal Opportunities) \$11; III (1) (b), (2) (Hung.). I.e., the pursuit of affirmative action goals is lawful, input quotas as a means are not-due to their rigidity.

81. KhatTan, supra note 33, at 223. 
equality; another one appeals to the expressive requirement of political equality.

The first version of the internal strategy attempts to ground the necessity constraint in the material requirement of political equality ${ }^{82}$ It must assume that electoral quotas have either a beneficial or an adverse effect on the distribution of opportunity in exerting political influence. Hence, when quotas are not necessary, they upset political equality—and the necessity constraint is thereby justified by the same value as quotas themselves. Yet this version of the internal strategy fails. In certain circumstances, the introduction of electoral quotas does not change the distribution of opportunities to exert political influence. Countries could, for instance, introduce gender electoral quotas as a means to solidify or merely expressively reaffirm the political egalitarian status quo rather than to redistribute objectionably distributed opportunities. In such cases, the concern for material political equality-i.e., equal opportunity to exert political influence-grounds no objection to introducing electoral quotas, even if the latter are unnecessary to achieve political equality. Hence, the necessity constraint cannot be justified by appeal to the material requirement of political equality alone.

The second version of the internal strategy relies on the expressive requirement of political equality in justifying the necessity constrainti.e., the requirement that "no member of the political community should be subject to treatment by the community that expresses their moral inequality or lesser worth as members of the political community." 83 This version succeeds. Arguably, applying electoral quotas when they are unnecessary to neutralize objectionable inequalities of opportunity to exert political influence expresses the lesser worth of those whose individual interests are-unnecessarily-set back or excluded from consideration due to electoral quotas. Thus, such treatment does not only violate general moral principles (see the external strategies above), but at once compromises the expressive requirement of political equality.

In conclusion, the Internal Restriction Approach leaves ample logical space for independent justifications of the necessity constraint that are coherent with it but are not grounded in political equality. At the same time, the constraint can also be derived from the Internal Restriction Approach itself, with due attention to the expressive dimension of political equality. The considerations coherent with the Internal Restriction Approach and the reason derived from it can individually or jointly account for why electoral quotas should only be instituted when necessary, and hence why they should be temporary measures rather than permanent features of our political institutions.

So far, I have accounted for the intuition that quotas are justified only if they are necessary. This accounts for why electoral quotas are more difficult

82. See supra Section III.

83. Mráz, supra note 47, at 268. 
to justify than alternative affirmative action measures aiming to realize political equality. But when are they necessary? Quotas are typically seen as necessary at least when unequal opportunities are a result of widespread, persistent social attitudes and practices that constitute active forms of exclusion-rather than, say, of economic inequalities that have lingered on resulting from past injustices that, in turn, have been eliminated. Such widespread, persistent attitudes, we may assume, could preclude the effective use of alternative affirmative action measures for the purpose of equalizing opportunities to exert political influence. ${ }^{84}$ This is just a tentative example of a type of objectionable political inequality that is unlikely to be eliminable without electoral quotas, in some circumstances. Whether electoral quotas are necessary for achieving political equality is an empirical and context-specific question; it is impossible to provide an a priori or general answer. I do not argue for or assume any such general empirical claim, but aim to provide a general justificatory strategy for mandatory electoral quotas. $^{85}$

Thus, the Internal Restriction Approach offers a relatively narrow but solid path to justify mandatory electoral quotas. It is revisionist insofar as it provides at least a pro tanto requirement for legal quotas and a defense against rights-based objections to them in a narrow set of cases-but it is not revisionist insofar as it still requires special justification for such quotas. This is as it should be: electoral quotas are seen as special, out-of-the-ordinary interventions, to be used in a narrow scope of cases. But when they are necessary, they should not be seen as merely optional. Then, and only then, they can serve as unique remedies for political inequality that do not restrict anyone's political participatory rights.

\section{SPECIFICATIONISM VS. PROPORTIONALISM}

My argument for electoral quotas may be seen as an application of a more general theory of apparent right-restrictions, to wit, specificationism. ${ }^{86}$ If this is so, the argument proposed here would be ineffective as addressed to those who do not subscribe to this general theory. Specificationism entails two claims that I do share: first, that upon reflection, the scope of rights does not extend as far as it first seems-and second, that in order

84. See Dahlerup, supra note 12, at 8-9. Or even if it were not impossible to achieve the affirmative action goal through alternative means, we might assume that using these alternative means instead of electoral quotas would take an unreasonable amount of time or social resources. Cf. Möller, supra note 40, at 194-196.

85. I thank an anonymous reviewer for pressing me to clarify this.

86. See Russ Shafer-Landau, Specifying Absolute Rights, 37 ARIz. L. REv. 209 (1995); Christopher Heath Wellman, On Conflicts Between Rights, 14 Law \& PHIL. 271 (1995); John Oberdiek, Specifying Rights Out of Necessity, 28 OxFord J. Legal STUd. 127 (2008); Oberdiek, infra note 89; José Juan Moreso, Ways of Solving Conflicts of Constitutional Rights: Proportionalism and Specificationism: Conflicts of Constitutional Rights: Proportionalism and Specificationism, 25 RAтіO JURIS 31 (2012). 
to properly specify this more limited scope, we need to engage in complex moral reasoning that includes a proper assessment of the normative underpinnings of the rights in question. The second claim is based on the further assumption that rights are not the ultimate building blocks of moral or legal reasoning. ${ }^{87}$ Yet this is where the similarities end between my argument and specificationism as a theory of rights and conflicts of rights.

Specificationism entails additional claims that I do not and need not endorse here. On this general theory, what seem to be conflicts of rights, properly understood, are never conflicts of rights at all. ${ }^{88}$ They are, instead, conflicts of pro tanto moral or legal reasons or interests that, once all of them are duly considered, conclude to the existence or nonexistence of a highly particular right-and to the highly specified scope of that right. ${ }^{89}$ For example, if journalists' freedom of expression and a public figure's privacy rights seem to conflict with regard to the latter person's criminal records or health data, the conflict is merely apparent. There is no such thing as a pro tanto right to freedom of expression that covers the journalist publishing these data, or a pro tanto right to privacy that covers the data subject's claim against such publication. It is either the case that journalists have a right to publish the data, or that the public figure has a right to privacy with regard to them-but both cannot be true. Specificationism holds that, in my terminology, external restrictions are just as much merely apparent restrictions on pro tanto rights as internal restrictions. However, this is not because the conflict of values involved is merely apparent. What is merely apparent on specificationism, instead, is the very existence of pro tanto rights. These additional claims contrast specificationism with the view that apparent conflicts of rights (at least sometimes) involve conflicts of real pro tanto rights; as well as with the view that accordingly, there is a distinction between merely infringing a (pro tanto) right and violating it-i.e., wrongfully or unjustifiably infringing a right-and specifically within the theory of fundamental-constitutional or international human -rights, also with the view that conflicts of (pro tanto) rights should be resolved by balancing or proportionality-based reasoning.

I do not need to endorse any of the previous, additional claims of specificationism for the sake of defending my argument. First, whether or not pro tanto rights are really rights, or merely a shorthand used to refer to legitimate interests or reasons that bear on how we specify all-things-considered

87. See, e.g., Oberdiek, supra note 86, at 131; Waldron, supra note 61 , at 503; cf. Shafer-Landau, supra note 86, at 214; Wellman, supra note 86, at 281.

88. See Wellman, supra note 86, at 277.

89. Cf. Oberdiek's apt formulation: "one argues towards and not from rights." John Oberdiek, Specifying Constitutional Rights, 27 Const. CommEnt. 231, 240 (2010) (original emphases). See also Wellman's earlier phrasing: "[i]nstead of being the essential moral building blocks from which theorists argue to conclusions, rights are actually moral edifices we argue towards." Wellman, supra note 86, at 281-282. While I agree that rights are not among the ultimate primitives of normative reasoning, I need not accept that pro tanto rights do not exist or have no intermediary role in legal and moral reasoning. 
rights, is immaterial for my account. All I argue for is that in some cases of apparent right-restrictions, contrary to appearances, the legitimate interest or reason grounding political participatory rights does not count in favor of a wider protection of these rights against electoral quotas. This claim may be, but need not be, phrased in the language of specificationism, or by reference to pro tanto rights grounded in legitimate interests or reasons. Second, it is not my intention in this paper to propose a general theory of rights. Instead, my argument follows a more piecemeal methodology, assuming that some apparent conflicts of values and rights (or the conflict between the respective underlying interests or justifying reasons of the latter, in specificationist talk) are merely apparent, while others are potentially real. I make a substantive claim about particular conflicts of rights-or their underlying interests or reasons-and values, and not a methodological, conceptual claim about what rights generally are or are not. ${ }^{90}$ Third, my argument concerns the substance of some moral and legal rights. Specificationists vary as to whether they apply specificationism to moral or legal rights. ${ }^{91}$ However, specificationism as a general theory of all legal rights conflicts, and of conflicts between fundamental rights in particular, ${ }^{92}$ has to navigate some heavy headwind. A vast proportion of the relevant legal instruments and jurisprudence rely extensively on the conception of conflicts of pro tanto rights and on the related infringement/violation distinction. Hence, if specificationism can be a theory of fundamental constitutional or international human rights at all, it is a highly revisionist theory. ${ }^{93}$ I have no similarly broad revisionist aspirations here.

\section{CONCLUSION}

In this paper, I have offered a political egalitarian account of electoral quotas, and I have argued that electoral quotas, when justified on this account, do not even restrict political participatory rights. This is the case if electoral quotas are necessary to ensure that some members of a political community are not victims of political inequalities that are responsive to some particular politically arbitrary characteristic of theirs. Further, I have argued that in such cases, electoral quotas are not merely morally desirable or permissible, but are, at least pro tanto, morally required. The argument has implications for several politically arbitrarily constituted groups of voters and candidates for elected offices, including-in some contexts-Roma and Traveller

90. See Shafer-Landau, supra note 86 , at 215.

91. On the significance of applying specificationism to moral vs. legal-more specifically, constitutional-rights, see Oberdiek, supra note 89, at 240-247.

92. Cf. Grégoire C. N. Webber, The Negotiable Constitution: On the Limitation of Rights (2009).

93. Cf. Barak's evaluation of Webber's specificationist theory of constitutional rights as "an alternative to the entire accepted notion of constitutional rights." BARAK, supra note 59, at 494 (reflecting on WEBBER, supra note 92). 
citizens, women citizens, or African-American citizens, among many other groups. I have not argued, though, for a specific understanding of which group-constitutive features are politically arbitrary-this account must await another occasion. What I have shown is that affirmative action in the form of electoral quotas need not be a means of realizing some overarching value-equal treatment, equal opportunity, antidiscrimination, equal dignity, etc.- that is external to the justificatory grounds of political participatory rights, and hence its realization need not infringe on the latter. Instead, the justification of electoral quotas can be seen as internal to the justificatory structure that also underpins political participatory rights - whereas the latter rights should not be seen as covering any interests or opportunities that would upset the realization of political equality. If this is right, a large extent of the moral costs of electoral quotas is, in some circumstances, illusory. Hence their justification is, to that extent, errortheoretical: we need not show that electoral quotas proportionately restrict political participatory rights if we can show that the former do not restrict the latter at all.

My argument also illustrates, I hope, the fruitfulness of a piecemeal methodological approach to the justification of affirmative action. This approach shirks from justifying affirmative action across different fields of life. Instead, affirmative action is justified by a closer look at the values characteristic of a particular domain, or the normative functions that a particular social practice or political institution is meant to fulfill. ${ }^{94}$ This paper followed this approach in providing a justification of electoral quotas rooted in a specific requirement of political equality.

On my account, electoral quotas are no panacea: they are not adequate remedies for all political inequalities related to politically arbitrary group membership. Nevertheless, they can serve as one of the important remedies for at least some of these inequalities. Justifying electoral quotas on political egalitarian grounds that liberal democracies subscribe to is one crucial step ahead for a political egalitarian theory of democracy and political participatory rights. While my argument does not rely on a very radical conception of political equality, it shows that fairly radical conclusions may be reached even on these grounds. Proponents of more radical conceptions of political equality may use the argumentative strategy and methodology applied here to draw even more radical conclusions.

94. See, e.g., Dworkin, supra note 46, 409-426, on higher education; cf. Dagan \& Dorfman, supra note 37 , at 1440 , on property. 